\title{
ANALISIS KELIMPAHAN IKAN KARANG DI FISH SHELTER DAN TERUMBU KARANG ALAMI PERAIRAN KARANG MELANTUT PANTAI REBO KECAMATAN SUNGAILIAT, KABUPATEN BANGKA
}

\section{CORAL FISH ANALYSIS IN FISH SHELTER AND NATURAL CORAL REEFS CORAL WATER KARANG MELANTUT REBO BEACH, SUNGAILIAT, BANGKA REGENCY}

\author{
Edwin Andrian ${ }^{1} *$, Sudirman Adibrata ${ }^{1}$, Suci Puspita Sari ${ }^{2}$ \\ ${ }^{1}$ Program Studi Manajemen Sumberdaya Perairan, Fakultas Pertanian Perikanan dan Biologi, \\ Universitas Bangka Belitung \\ ${ }^{2}$ Program Studi Ilmu Kelautan, Fakultas Pertanian Perikanan dan Biologi, \\ Universitas Bangka Belitung
}

Kampus Terpadu UBB, Gedung Teladan, Bangka, Kepulauan Bangka Belitung, 33172 Indonesia Email: edwinandrian77@gmail.com

\begin{abstract}
ABSTRAK
Pantai Rebo merupakan wilayah yang memiliki potensi sumberdaya laut seperti ekosistem terumbu karang, ikan dan sebagainya. Pantai rebo juga memiliki potensi sumberdaya mineral yang tinggi seperti biji timah. Potensi sumberdaya mineral tersebut menyebabkan adanya aktivitas penambangan di perairan Pantai Rebo. Kegiatan pertambangan timah di laut menimbulkan masalah terhadap ekosistem terumbu karang dan biota laut lainnya. Upaya penanggulangan masalah tersebut diantaranya rehabilitasi ekosistem seperti transplantasi terumbu karang serta pembuatan dan penenggelaman Fish Shelter di perairan Pantai Rebo. Penelitian ini bertujuan untuk mengetahui jumlah spesies dan kelimpahan ikan karang di lokasi Fish Shelter dan di Terumbu Karang Alami(TKA) Perairan Karang Melantut Pantai Rebo serta menganalisis perbandingan kelimpahan ikan karang di kedua lokasi tersebut. Penelitian ini dilakukan pada Bulan Juli 2019, pengambilan data ikan karang dilakukan dengan metode Belt Transect dan Visual Sensus, sedangkan pengambilan data terumbu karang dilakukan dengan metode Line Intersept Transect(LIT). Hasil penelitian menunjukkan kelimpahan ikan karang di stasiun 1 pada Terumbu Karang Alami(TKA) terdiri dari 8 famili dan 16 spesies dengan jumlah individu sebanyak 110 ind/ha serta 10 famili dan 12 spesies dengan jumlah individu sebanyak 125 ind/ha di lokasi Fish Shelter. Pada stasiun 2 kelimpahan ikan karang di Terumbu karang Alami(TKA) terdiri dari 7 famili dan 12 spesies dengan jumlah individu sebanyak 120 ind/ha serta 10 famili dan 15 spesies dengan jumlah individu sebanyak 134 ind/ha di lokasi Fish Shelter. Hasil uji one way anova pada stasiun 1 perbandingan kelimpahan ikan karang di lokasi Fish Shelter dan TKA dengan nilai signifikansi 0,177, maka $\mathrm{H}_{0}$ diterima. Sedangkan stasiun 2 perbandingan kelimpahan ikan karang di lokasi Fish Shelter dan TKA dengan nilai signifikan 0,743 , maka $\mathrm{H}_{0}$ diterima, artinya Perbandingan kelimpahan Ikan karang di fish shelter dan TKA pada stasiun 1 dan 2 sama-sama tidak ada perbedaan nyata dari segi jumlah kelimpahan spesies.
\end{abstract}

Kata kunci : ikan karang; kelimpahan; fish shelter; terumbu karang alami

\begin{abstract}
Rebo Beach is an area that has potential for marine resources such as coral reef ecosystems, fish and so on. Rebo beach also has a high potential for mineral resources such as lead seeds. The potential of these mineral resources has caused mining activities in the rebo coast waters. Tin mining activities at sea cause problems for coral reef ecosystems and other marine biota. Efforts to overcome these problems include rehabilitation of ecosystems such as coral reef transplants and the creation and sinking of Fish Shelter in Rebo Coastal Waters. This study aims to determine the number of species and abundance of reef fishes in the Fish Shelter location and in the Natural Coral Reef (NCR) of the Coral Waters of Rebo Beach and to analyze the comparison of coral fish abundance in the two locations. This research was conducted in July 2019, reef fish data collection was carried out by the Belt Transect and Visual Census methods, while the coral reef data collection was carried out by the Line Intersept Transect (LIT) method. The results showed an abundance of reef fish at Station 1 on the Natural Coral Reef (NCR) consisting of 8 families and 16 species with a total of 110 individuals / ha and 10 families and 12 species with 125
\end{abstract}


individuals / ha at the Fish Shelter site. At station 2 the abundance of reef fish in the Natural Coral Reef (NCR) consists of 7 families and 12 species with a total of 120 individuals / ha and 10 families and 15 species with a total of 134 individuals / ha at the Fish Shelter site. One way ANOVA test results at Station 1 comparisons of coral fish abundance at Fish Shelter and Natural Coral Reef locations with a significance value of 0.177 , then $\mathrm{HO}$ is accepted. While station 2 compares the abundance of reef fishes at Fish Shelter and natural Coral Reef locations with a significant value of 0.743 , then HO is accepted, meaning that Comparison of abundance of reef fishes in fish shelter and Natural Coral Reef at stations 1 and 2 there is no significant difference in terms of species abundance.

Keywords: coral fish; abundance; fish shelter; natural coral reefs

\section{PENDAHULUAN}

Pantai Rebo adalah daerah yang berada pada wilayah administrasi Desa Rebo Kabupaten Bangka Provinsi Kepulauan Bangka Belitung. Pantai Rebo memiliki potensi sumberdaya laut seperti ekosistem terumbu karang, ikan dan biota laut yang bernilai ekonomis tinggi lainnya. Pantai rebo juga menyimpan potensi sumberdaya mineral yang tinggi yaitu biji timah. Potensi sumberdaya alam tersebut salah satunya terdapat di Karang Melantut. Karang Melantut merupakan lokasi terumbu karang yang berjarak 5,5 km dari Pantai Rebo. Karang Melantut merupakan salah satu daerah perairan Pantai Rebo yang masuk dalam kawasan sebaran Izin Usaha Penambangan (IUP) timah laut yang dulunya terdapat Kapal Isap Produksi (KIP) milik PT Timah Tbk (Syari, 2016).

Kegiatan penambangan timah laut atau lepas pantai yang dilakukan di perairan pantai rebo khususnya di Karang Melantut menghasilkan tailing (sedimentasi) sehingga mengakibatkan terjadinya peningkatan tingkat kekeruhan di sekitar perairan Karang Melantut Pantai Rebo. Hal ini ditegaskan juga oleh Syari (2016) bahwa permasalahan wilayah pesisir di provinsi Kepulauan Bangka Belitung adalah terdapatnya penambangan timah yang menimbulkan sedimentasi dan berpotensi mencemari perairan.

Kerusakan terumbu karang adalah perubahan sifat fisik dan atau hayati terumbu karang (Keputusan Menteri Negara Lingkungan Hidup No. 04 tahun 2001). Kerusakan ekosistem terumbu karang yang terjadi di perairan Pantai Rebo khususnya di Karang Melantut disebabkan oleh faktor aktifitas penambangan timah lepas pantai dan TI Apung yang saat ini masih beroperasi di pesisir Pantai Rebo. Namun limbah tailing yang dihasilkan dari kegiatan tersebut sangat berpengaruh terhadap kehidupan karang. Salah satu indikator kesehatan ekosistem terumbu karang dapat dilihat dari tinggirendahnya kelimpahan dari ikan-ikan karang yang berada di perairan tersebut. Selain Kerusakan ekosistem terumbu karang yang ditimbulkan oleh aktifitas penambangan laut juga menyebabkan berkurangnya hasil tangkapan ikan serta daerah penangkapan nelayan yang menjadi semakin jauh.

Salah satu kebijakan pemerintah daerah Provinsi Kepulauan Bangka Belitung dan pelaku usaha dalam memperbaiki kerusakan lingkungan yang ditimbulkan oleh kegiatan penambangan timah lepas pantai yaitu dengan kegiatan reklamasi dan rehabilitasi ekosistem sumberdaya perairan. Salah satu upaya yang diberikan yakni melakukan pembuatan dan penenggelaman fish shelter (Rumah Ikan) di Perairan Pantai Rebo salah satunya di Karang Melantut yang terkena dampak kerusakan dari aktifitas penambangan tersebut. Kegiatan penenggelaman fish Shelter bertujuan untuk menyediakan habitat baru bagi ikan karang pada perairan tersebut, serta untuk menarik ikan khususnya ikan karang untuk datang di sekitar lokasi penempatan, dan diharapkan dapat menjadi tempat berkembang biak bagi ikan serta menambah kelimpahan dan keanekaragaman ikan dan terumbu karang. Selain itu, masih belum adanya informasi mengenai kelimpahan ikan karang di daerah penenggelaman fish shelter Karang Melantut Pantai Rebo sehingga perlu dilakukan penelitian mengenai kelimpahan ikan karang di fish shelter dalam upaya reklamasi dan rehabilitasi laut di daerah pasca penambangan timah lepas pantai.

\section{METODE PENELITIAN}

Penelitian ini dilakukan pada bulan Juli 2019. Lokasi penelitian di perairan karang Melantut Desa Rebo Kabupaten Bangka. Tahapan dalam penelitian terdiri dari 3 tahap yaitu : 1) survey lapangan 2) pengambilan data dan pengumpulan data lapangan 3) analisis data dan pengolahan data.

Penentuan stasiun penelitian dilakukan berdasarkan lokasi penenggelaman fish shelter. Metode ini merupakan teknik 


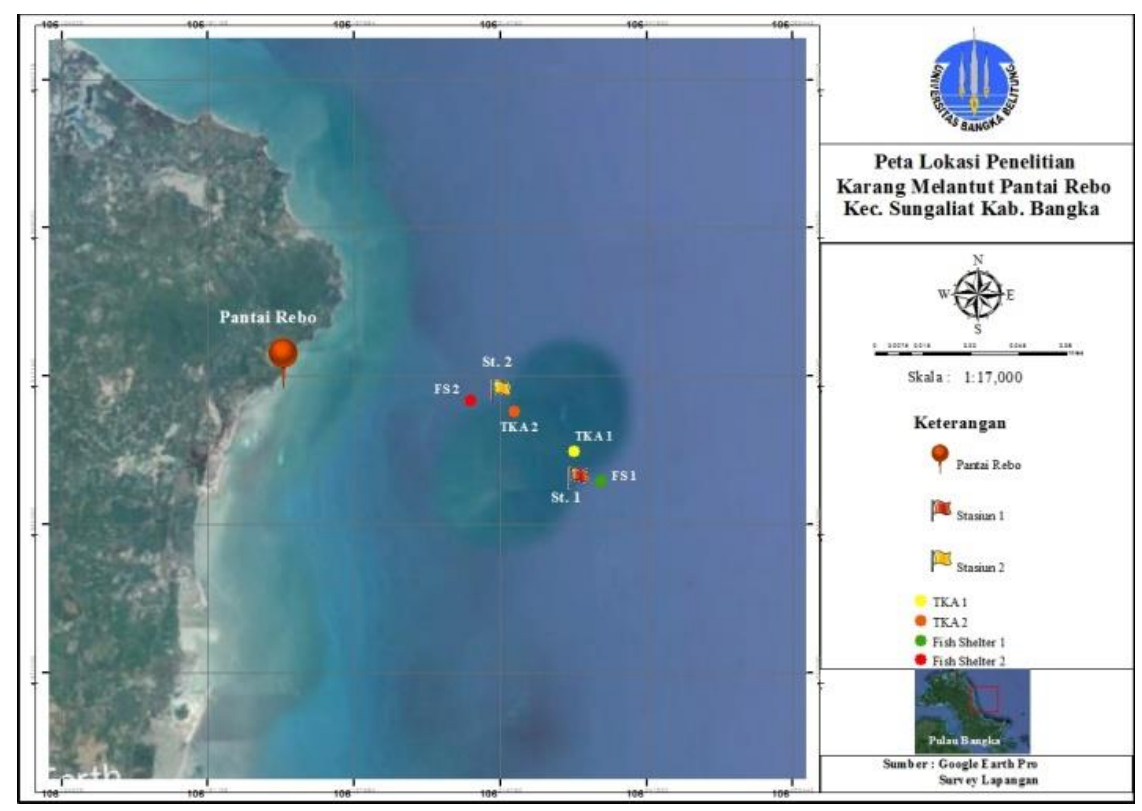

Gambar 1. Peta Lokasi Penelitian

pengambilan sampel yang digunakan berdasarkan titik koordinat yang telah ada yaitu lokasi titik penenggelaman fish shelter. Sedangkan pada pengambilan data terumbu karang yakni menggunakan metode purposive sampling. Metode ini merupakan penentuan lokasi berdasarkan keterwakilan persebaran penutupano terumbu karang (Setyobudiandi, 2009). Lokasi penelitian terdiri dari 2 stasiun penelitian dimana pada masing-masing stasiun terdapat 2 sub stasiun yaitu di Fish Shelter dan di Terumbu Karang Alami Perairan Karang Melantut Pantai Rebo.

Pengambilan data ikan karang dilakukan pada dua titik lokasi yakni pada lokasi Terumbu Karang Alami(TKA) dan di lokasi penenggelaman Fish Shelter. Pengambilan data ikan karang pada lokasi terumbu karang alami menggunakan metode transek sabuk (Belt Transect) menggunakan line transect dengan pendekatan visual sensus pada garis transek sabuk (Hill dan Wilkinson, 2004). Sedangkan pada pengambilan data ikan karang di Fish Shelter menggunakan metode Visual Census dan menggunakan alat bantu kamera bawah air.

Penyelam akan menyusuri Fish Shelter sambil mengidentifikasi ikan dengan mengunakan gambar slide ikan yang ada (sudah dilaminating), ikan yang terlihat langsung dicatat di sabak (Alat Tulis Kedap Air) dan ikan yang tidak bisa diidentifikasi secara langsung oleh peneliti diberikan kode pada gambar slide yang ada atau menuliskan ciri-cirinya serta didokumentasikan dalam bentuk foto yang nantinya akan di identifikasi di darat. Jarak pada pengamatan di sesuaikan dengan ukuran Fish Shelter yakni sejauh 2,5 m ke kanan dan 2,5 m ke kiri. Lebar batasan sampling tersebut sudah merupakan standar batas penglihatan bawah air dengan menggunakan kacamata selam (masker) pada saat pengamatan (Hill dan Wilkinson, 2004).

Pengambilan data karang dilakukan dengan metode LIT (Line Intercept Transect) English et al. (1994) dengan panjang line 50 meter sejajar garis pantai. Metode ini digunakan untuk mengetahui persen tutupan terumbu karang. Satuan yang digunakan berdasarkan metode ini adalah (\%). Data karang yang diukur adalah bentuk pertumbuhan karang dan identifikasi hingga tingkat genus menggunakan buku identifikasi karang Suharsono (2010) dan Veron (2000).

Data parameter lingkungan diambil secara langsung dilapangan (in situ) meliputi parameter suhu, kecerahan, kecepatan arus, salinitas, $\mathrm{pH}$, dan secara tidak langsung (ex situ) meliputi parameter DO yang akan

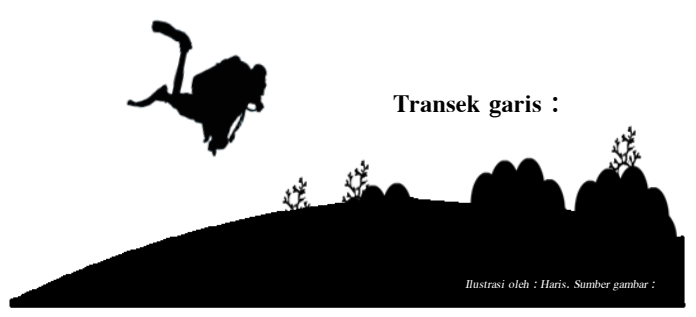

Gambar 2. Ilustrasi Pengambilan data ikan karang 


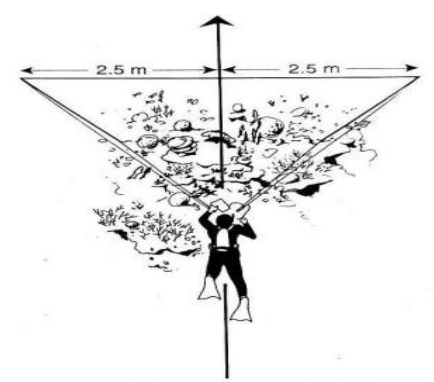

Gambar 3. Ilustrasi pengambilan terumbu karang

data

dianalisa di laboratorium Manajemen Sumberdaya Perairan, Universitas Bangka Belitung.

\section{Analisis Data}

Kelimpahan relatif setiap jenis ikan dilakukan perhitungan prsentase jumlah. Kelimpahan relatif adalah perbandingan antara jumlah individu dan jumlah total seluruh individu (Setyobudiandi, 2009).

$$
\mathrm{Kr}=\frac{n i}{N} \times 100 \%
$$

Keterangan: $\mathrm{Kr}=$ Kelimpahan relatif; $n i=$ Jumlah individu spesies ke-I; $\mathrm{N}=$ Jumlah total individu semua spesies

Indeks keanekaragaman ikan karang ditentukan dengan menggunakan indeks Shannon-Wiener.

$$
\mathrm{H}^{\prime}=-\sum \mathrm{Pi} \text { In Pi dimana } \mathrm{Pi}=\frac{n i}{N}
$$

Keterangan: $H^{\prime}=$ Indeks keanekaragaman; $\mathrm{pi}=$ Proporsi kelimpahan dari spesies ke-i $(\mathrm{ni} / \mathrm{N}) ; \mathrm{ni}=$ Jumlah Individu (i); $\mathrm{N}=$ Total Jumlah Individu

Indeks keseragaman digunakan untuk mengetahui penyebaran jumlah individu tiap spesies ikan karang. Indeks keseragaman dihitung dengan rumus sebagai berikut:

$$
\mathrm{E}=\frac{H^{\prime}}{H \operatorname{maks}}=\frac{H^{\prime}}{\operatorname{In} S}
$$

Keterangan: $\mathrm{E}=$ Indek Keseragaman; $\mathrm{H}^{\prime}=$ Indeks Keanekaragaman Shannon-Wiener; $\mathrm{H}_{\text {maks }}=$ Keanekaragaman Maksimum; $\mathrm{S}=$ Jumlah Spesies

Pendugaan indeks keseragaman (E), dimana semakin besar nilai $E$ menunjukkan kelimpahan yang hampir seragam dan merata antar spesies (Odum, 1971). Nilai dominansi ditentukan dengan rumus:

$$
\mathrm{C}=\sum_{i=1}^{n} p_{i}^{2}
$$

Keterangan : $C=$ Indeks Dominansi; $P_{\mathrm{i}}=$ Proporsi jumlah individu pada spesies ikan karang ke-i

Menurut (Odum, 1971) pengelompokkan indeks dominansi dalam suatu komunitas dinyatakan dalam kategori nilai sebagai berikut $0<C=0,3$ : Dominansi rendah; $0,3<C=0,6$ : Dominansi sedang; $0,6<C=1$ : Dominansi tinggi

Pengolahan data One Way Anova menggunakan program SPSS versi 25. Uji One Way Anova mempunyai taraf signifikansi sebesar $95 \%$ atau nilai eror $5 \%$ sama dengan 0,05 . Kriteria pengambilan keputusan yaitu $\mathrm{H}_{0}$ diterima jika P-value $>0,05$ maka perbandingan kelimpahan ikan pada fish shelter di kedua stasiun tidak berbeda nyata. $\mathrm{H}_{0}$ ditolak jika P-value $<0,05$ maka perbandingan kelimpahan ikan ikan pada fish shelter di kedua stasiun maka berbeda nyata (Syari, 2016).

Data persen tutupan komunitas karang yang didapatkan dengan menggunakan metode transek garis (Line Intercept Transect) dihitung dengan menggunakan rumus (English et al., 1994) sebagai berikut:

$$
N i=\frac{l i}{L} X 100 \%
$$

Keterangan : $\mathrm{Ni}=$ persen penutupan komunitas karang (\%); li = panjang total life form jenis ke-i $(\mathrm{cm}) ; L=$ panjang transek (m).

Tabel 4. Kriteria Ikan karang berdasarkan P2O-LIPI, 2013

\begin{tabular}{ccc} 
Kisaran (H) Arifin (2017) & Kisaran (E) Odum (1971) & Kisaran (C) Odum (1971) \\
\hline $\mathrm{H}<1$ : Rendah & $\mathrm{E}<1$ : Tinggi & $0<\mathrm{C}=0,3$ : Rendah \\
$1 \leq \mathrm{H}<3$ : Sedang & $0,4<\mathrm{E}<0,6$ :Sedang & $0,3<\mathrm{C}=0,6$ : Sedang \\
$\mathrm{H}>3$ : Tinggi & $\mathrm{E}<0,4$ : Rendah & $0,6<\mathrm{C}=1$ : Tinggi
\end{tabular}


Penilaian kondisi terumbu karang dilakukan berdasarkan nilai presentase penutupan karang hidup (life coral) mengacu kepada Keputusan Menteri Lingkungan Hidup No.04 Tahun 2001.

\section{HASIL DAN PEMBAHASAN}

\section{Kelimpahan Ikan Karang pada ekosistem Terumbu Karang Alami(TKA)}

Kelimpahan ikan karang yang teramati pada stasiun 1 dan 2 Perairan Karang Melantut Pantai Rebo di fish shelter dan ekosistem Terumbu Karang Alami (TKA) ditampilkan pada Tabel 6 dan 8. Adapun kehadiran famili ikan karang yang berada pada stasiun 1 Perairan Karang Melantut Pantai Rebo ditampilkan pada Tabel 7.
Kelimpahan ikan karang Pada ekosistem Terumbu Karang Alami(TKA) di stasiun 1 terdiri dari 8 famili dan 16 spesies ikan karang dengan jumlah indivudu sebanyak 110 ind/ha. Spesies ikan karang yang memiliki tingkat kelimpahan yang cukup tinggi yaitu spesies Caesio cuning, Chalotomus spiniden, Lutjanus carponotatus, Chaetodon octofaciatus, Pomacentrus brachialis dan Lutjanus russelli. Sedangkan pada stasiun 2 terdiri dari 7 famili dan 12 spesies ikan karang dengan jumlah individu sebanyak 120 ind/ha. spesies ikan karang yang memiliki tingkat kelimpahan yang cukup tinggi yaitu spesies Pomacentrus brachialis, Lutjanus vitta Acreichthys tomentosus, Pomacentrus javanicus, dan Chaetodon octofaciatu.

Tabel 5. Kriteria persentase tutupan karang hidup menurut KEPMEN LH No 4 Tahun 2001.

\begin{tabular}{cc}
\hline Kriteria & Persentase (\%) \\
\hline Buruk & $0-24.9$ \\
Sedang & $25-49.9$ \\
Baik & $50-74.9$ \\
Baik sekali & $75-100$ \\
\hline
\end{tabular}

Tabel 6. Spesies Ikan Karang pada stasiun 1 Perairan Karang Melantut

\begin{tabular}{llcc}
\hline \multicolumn{1}{c}{ Spesies } & \multicolumn{1}{c}{ Nama Lokal } & Fish Shelter & TKA \\
\hline Scolopsis aurata & Kurisi Pasir & 0 & 5 \\
Pomacentrus auriventris & Blu Kuning & 0 & 2 \\
Abudefduf bengalensisi & Betok Strip Ijo & 0 & 7 \\
Pomacentrus brachialis & Betok Laut & 0 & 10 \\
Neoglyphidodon nigroris & Daun Bijur & 0 & 7 \\
Amphiprion clarkii & Giru Pasir & 0 & 3 \\
Amphiprion ocellaris & Badut & 0 & 5 \\
Chaetodon octofaciatus & Kepe-kepe & 0 & 11 \\
Lethrinus lentjan & Lencam & 0 & 2 \\
Lutjanus carponotatus & Seruit Ginggang & 0 & 10 \\
Lutjanus monostigma & Kakap & 0 & 1 \\
Lutjanus russelli & Tande-tande & 8 & 12 \\
Caesio cuning & Ekor Kuning & 32 & 18 \\
Chalotomus spinidens & Kakak Tua & 0 & 10 \\
Halichoeres javanicus & Keling & 7 & 6 \\
Hemigymnus melapterus & Ketarap & 0 & 1 \\
Labroides dimidiatus & Dokter & 18 & 0 \\
Siganus guttatus & Baronang & 16 & 0 \\
Neoglyphidodon bonang & Daun Bijur & 2 & 0 \\
Pomacentrus javanicus & Betok Laut & 9 & 0 \\
Clorurus sordidus & Kakak Tua & 5 & 0 \\
Amanses scopas & Sapu-sapu & 2 & 0 \\
Diagramma pictum & Seminyak & 3 & 0 \\
Platax pinnatus & Tudung Belangak & 8 & 110 \\
Apogon uristigma & Capungan & 15 & \\
& TotaL & 125 & \\
\hline & & & 0 \\
\hline
\end{tabular}


Tabel 7. Famili Ikan Karang pada Stasiun 1 Perairan Karang Melantut

\begin{tabular}{lcc}
\hline \multicolumn{1}{c}{ Famili } & Fish Shelter & TKA \\
\hline Labridae & $\sqrt{ }$ & $\sqrt{ }$ \\
Siganidae & $\sqrt{ }$ & $\mathrm{X}$ \\
Lutjanidae & $\sqrt{ }$ & $\sqrt{ }$ \\
Pomacentridae & $\sqrt{ }$ & $\sqrt{ }$ \\
Scaridae & $\sqrt{ }$ & $\sqrt{ }$ \\
Triachantidae & $\sqrt{ }$ & $\mathrm{X}$ \\
Caesionidae & $\sqrt{ }$ & $\sqrt{ }$ \\
Haemulidae & $\sqrt{ }$ & $\mathrm{X}$ \\
Ephippidae & $\sqrt{ }$ & $\mathrm{X}$ \\
Apogonidae & $\sqrt{ }$ & $\mathrm{X}$ \\
Nemipteridae & $\mathrm{X}$ & $\sqrt{ }$ \\
Chaetodontidae & $\mathrm{X}$ & $\sqrt{ }$ \\
Lethrinidae & $\mathrm{X}$ & $\sqrt{ }$ \\
\hline
\end{tabular}

Hasil pengamatan pada stasiun 1 menunjukkan sedikitnya kelimpahan ikan karang dibandingkan dengan stasiun 2 pada ekosistem Terumbu Karang Alami(TKA). Hal ini dikarenakan adanya perbedaan sejumlah kehadiran atau ketidak merataan kehadiran spesies ikan karang yang disebabkan karena perbedaan persentase tutupan karang di masing-masing stasiun. Tingginya nilai tutupan Dead Coral Algae (DCA) merupakan penyebab sedikitnya kelimpahan ikan di sasiun 1 perairan Karang Melantut Pantai Rebo. Pertumbuhan algae sendiri dapat dipengaruhi oleh faktor lingkungan seperti oksigen terlarut (DO), Menurut Hendrik (2017) kisaran DO yang baik untuk perkembangan dan pertumbuhan algae $>6$ $\mathrm{mg} / \mathrm{L}$.

\section{Kelimpahan Ikan Karang pada Fish Shelter}

Kelimpahan ikan karang pada pada Fish Shelter di stasiun 1 terdiri dari 10 famili dan 12 spesies ikan karang dengan jumlah individu sebanyak 125 ind/ha. Sedangkan kelimpahan ikan karang pada stasiun 2 terdiri dari 10 famili dan 15 spesies ikan karang dengan jumlah individu sebanyak 134 ind/ha. Hasil ini menunjukan bahwa kelimpahan ikan karang pada Fish Shelter di stasiun 1 lebih sedikit dibandingkan yang ada di stasiun 2 . Hal ini dikarenakan Fish shelter di stasiun 2 berada pada posisi yang terlindung dibandingkan pada stasiun 1 yang menghadap ke laut lepas. Fish Shelter yang menghadap ke laut lepas akan lebih rentan terhadap pengaruh sedimentasi dan gelombang besar dari laut lepas. Jumlah kelimpahan ikan baik kehadiran individu pada famili ikan karang yang ditemukan pada fish shelter lebih banyak dibandingkan dengan yang berada pada ekosistem Terumbu Karang Alami(TKA). Keberadaan ikan karang pada lokasi Fish Shelter di masing-masing stasiun dikarenakan adanya kerusakan pada ekosistem Terumbu Karang Alami(TKA) di Perairan Karang Melantut yang disebabkan oleh penangkapan nelayan (bagan, jaring, pancing dan bubu) yang tinggi serta aktifitas penambangan disekitar Lokasi.

Aktivitas Penambangan Laut di sekitar Pantai Rebo mengakibatkan ikan beruaya mencari tempat baru untuk berlindung serta mencari makan. Selain itu, keberadaan ikan karang pada lokasi Fish Shelter dikarenakan adanya proses rantai makanan yang berurutan dan terdapatnya sumber makanan. Menurut Madduppa (2006) tumbuhnya bakteri dan mikroorganisme pada bagianbagian Fish Shelter Sehingga menarik ikanikan kecil yang ingin mencari makan. Adapun famili ikan karang yang berada pada stasiun 2 Perairan Karang Melantut Pantai Rebo ditampilkan pada Tabel 9.

\section{Indeks Keanekaragaman, Keseragaman, dan Dominansi Ikan Karang di Perairan Karang Melantut Pantai Rebo}

Pada stasiun 1 nilai indeks keanekaragaman ikan karang di Perairan Karang Melantut didapatkan dengan nilai rata-rata 2,371. Sedangkan pada stasiun 2 didapatkan nilai rata-rata 2,292. Berdasarkan hasil nilai indeks keanekaragaman yang didapatkan di Perairan Karang Melantut Pantai Rebo dikategorikan dalam kategori sedang.

Hasil nilai indeks keseragaman (E) yang didapatkan pada stasiun 1 dan 2 di Perairan Karang Melantut Pantai Rebo sama-sama dalam kategori tinggi. Pada stasiun 1 hasil indeks keseragaman yang didapatkan yaitu dengan nilai rata-rata 0,901 sedangkan pada stasiun 2 nilai indeks keseragaman yang didapatkan yaitu dengan nilai rata-rata 0,885 .

Hasil nilai indeks dominansi (C) yang didapatkan pada stasiun 1 yaitu dengan nilai rata-rata 0,113 yang dikategorikan dalam kategori sedang. Sedangkan nilai indeks dominansi (C) yang didapatkan pada stasiun 2 Karang yaitu dengan nilai rata-rata 0,126 dikategorikan dalam kategori rendah.

Hasil perhitungan nilai indeks keanekaragaman $\left(\mathrm{H}^{\prime}\right)$, indeks keseragaman (E) dan indeks dominansi (C) ikan karang pada di Perairan Karang Melantut Pantai Rebo disajikan pada Tabel 10 dan Tabel 11. 
Tabel 8. Spesies Ikan Karang pada Stasiun 2 Perairan Karang Melantut

\begin{tabular}{|c|c|c|c|}
\hline Spesies & Nama Lokal & Fish Shelter & TKA \\
\hline Pomacentrus brachialis & Betok Laut & 0 & 20 \\
\hline Acanthochromis polyacanthus & Betok Laut & 0 & 4 \\
\hline Pomacentrus javanicus & Betok Laut & 0 & 10 \\
\hline Clorurus sordidus & Kakak Tua & 9 & 5 \\
\hline Chelmon rostratus & Kepe-kepe & 0 & 10 \\
\hline Chaetodon octofasciatus & Kepe-kepe & 0 & 15 \\
\hline Cephalopholis boenak & Kerapu Karet & 0 & 2 \\
\hline Lutjanus vitta & Seruit Ginggang Karang & 0 & 18 \\
\hline Lutjanus rivulatus & Seruit Ginggang & 0 & 6 \\
\hline Choerodon oligacanthus & Ketarap & 2 & 8 \\
\hline Pseudalutarius nasicornis & Ayem-ayem & 0 & 6 \\
\hline Acreichthys tomentosus & Ayem-ayem & 0 & 16 \\
\hline Siganus javus & Libem & 28 & 0 \\
\hline Siganus virgatus & Libem Karang & 15 & 0 \\
\hline Siganus guttatus & Baronang & 10 & 0 \\
\hline Halichoeres javanicus & Ketarap & 5 & 0 \\
\hline Hologymnosus doliatus & Ketarap & 8 & 0 \\
\hline Chaerodon anchorago & Ketarap Merah & 4 & 0 \\
\hline Arathron stellatus & Buntal & 6 & 0 \\
\hline Taeniura lymma & Pari Karang & 1 & 0 \\
\hline Caesio cuning & Ekor Kuning & 34 & 0 \\
\hline Plectropomus maculatus & Kerapu Sunok & 2 & 0 \\
\hline Lutjanus biguttatus & Kakap & 5 & 0 \\
\hline Diagramma pictum & Seminyak & 2 & 0 \\
\hline Platax pinnatus & Tudung Belangak & 3 & 0 \\
\hline \multicolumn{2}{|c|}{ TOTAL } & 134 & 120 \\
\hline
\end{tabular}

Tabel 9. Famili Ikan Karang pada Stasiun 2 Perairan Karang Melantut.

\begin{tabular}{ccc}
\hline Famili & Fish Shelter & TKA \\
\hline Siganidae & $\sqrt{ }$ & $\mathrm{X}$ \\
Labridae & $\sqrt{ }$ & $\sqrt{ }$ \\
Tetraodontidae & $\sqrt{ }$ & $\mathrm{X}$ \\
Dasyatidae & $\sqrt{ }$ & $\mathrm{X}$ \\
Caesionidae & $\sqrt{ }$ & $\mathrm{X}$ \\
Serranidae & $\sqrt{ }$ & $\sqrt{ }$ \\
Scaridae & $\sqrt{ }$ & $\sqrt{ }$ \\
Lutjanidae & $\sqrt{ }$ & $\sqrt{ }$ \\
Haemulidae & $\sqrt{ }$ & $\mathrm{X}$ \\
Ephippidae & $\sqrt{ }$ & $\mathrm{X}$ \\
Pomacentridae & $\mathrm{X}$ & $\sqrt{ }$ \\
Chaetodontidae & $\mathrm{X}$ & $\sqrt{ }$ \\
Seranidae & $\mathrm{X}$ & $\sqrt{ }$ \\
Monacantidae & $\mathrm{X}$ & $\sqrt{ }$ \\
\hline
\end{tabular}

Hasil indeks keanekaragaman yang didapatkan pada stasiun 1 dan 2 di Perairan Karang Melantut Pantai Rebo dalam kategori sedang. Pada stasiun 1 hasil indeks keanekaragaman yang didapatkan yaitu dengan nilai rata-rata 2,371. Sedangkan pada stasiun 2 di Karang Melantut Rebo nilai indeks keanekaragaman didapatkan dengan nilai rata-rata 2,292. Nilai indeks keanekargaman pada stasiun 1 lebih tinggi dibandingkan dengan nilai keanekaragaman pada stasiun 2, hal ini dikarenakan stasiun 1 berada pada derah yang terlindung sehingga membuat ikan banyak berkumpul didaerah fish shelter yang menghadap ke pulau Bangka.

Hasil nilai indeks keseragaman (E) yang didapatkan pada stasiun 1 dan 2 Perairan Karang Melantut Pantai Rebo sama-sama dalam kategori tinggi. Pada Perairan Rebo hasil indeks keseragaman yang didapatkan yaitu dengan nilai rata-rata 0,901. 
Sedangkan pada Karang Melantut Rebo nilai indeks keseragaman didapatkan dengan nilai rata-rata 0,885. Berdasarkan nilai indeks keseragaman jenis ikan karang pada fish shelter yang didapatkan pada kedua lokasi penelitian menandakan bahwa jumlah jenis ikan karang dalam populasi besar dan komunitas ikan pada fish shelter stabil.

Hasil nilai indeks dominansi (C) yang didapatkan pada stasiun 1 Perairan Karang Melantut Pantai Rebo yaitu dengan nilai ratarata 0,113 , sehingga dikategorikan dalam kategori rendah. Sedangkan nilai indeks dominansi (C) yang didapatkan pada stasiun 2 di Perairan Karang Melantut Pantai Rebo yaitu dengan nilai rata-rata 0,126 sehingga dikategorikan dalam kategori rendah. Hal ini menunjukan bahwa di kedua stasiun samasama memiliki nilai indeks Dominansi yang rendah. Maka dalam hal ini dapat diartikan pada perairan tersebut tidak ada jenis atau spesies yang mendominasi. Kondisi ini dikarenakan lokasi fish shelter di Karang Melantut Rebo berdekatan dengan ekosistem terumbu karang.

Tabel 10. Nilai rata-rata indeks keanekaragaman $\left(H^{\prime}\right)$, keseragaman $(E)$, dan dominansi (C) ikan karang pada stasiun 1 Perairan Karang Melantut.

\begin{tabular}{|c|c|c|c|c|c|}
\hline Stasiun & Lokasi & $\mathrm{H}^{\prime}$ & $E$ & $\mathrm{C}$ & Keterangan \\
\hline & TKA & 2,542 & 0,917 & 0,090 & $\begin{array}{c}\text { Sedang, Tinggi, } \\
\text { Rendah }\end{array}$ \\
\hline S1 & Fish Shelter & 2,199 & 0,885 & 0,136 & $\begin{array}{c}\text { Sedang, Tinggi, } \\
\text { Rendah }\end{array}$ \\
\hline
\end{tabular}

Tabel 11. Nilai rata-rata indeks keanekaragaman $\left(H^{\prime}\right)$, keseragaman $(E)$, dan dominansi $(C)$ ikan karang pada stasiun 2 Perairan Karang Melantut.

\begin{tabular}{|c|c|c|c|c|c|}
\hline Stasiun & Lokasi & $\mathrm{H}^{\prime}$ & $E$ & $\mathrm{C}$ & Keterangan \\
\hline \multirow[t]{2}{*}{$\mathrm{S} 2$} & TKA & 2,320 & 0,934 & 0,110 & $\begin{array}{c}\text { Sedang, Tinggi, } \\
\text { Rendah }\end{array}$ \\
\hline & Fish Shelter & 2,263 & 0,836 & 0,141 & $\begin{array}{c}\text { Sedang, Tinggi, } \\
\text { Rendah }\end{array}$ \\
\hline
\end{tabular}

\begin{tabular}{|c|c|c|c|c|c|}
\hline \multirow{2}{*}{ JUMLAH } & \multicolumn{4}{|c|}{ ANOVA } & \multirow[b]{2}{*}{ Sig. } \\
\hline & $\begin{array}{l}\text { Sum of } \\
\text { Squares }\end{array}$ & df & Mean Square & $F$ & \\
\hline Between Groups & 86,012 & 1 & 86,012 & 1,923 & ,177 \\
\hline Within Groups & 1162,667 & 26 & 44,718 & & \\
\hline Total & 1248,679 & 27 & & & \\
\hline \multicolumn{6}{|c|}{ ANOVA } \\
\hline & $\begin{array}{l}\text { Sum of } \\
\text { Squares }\end{array}$ & df & Mean Square & F & Sig. \\
\hline Between Groups & 7,585 & 1 & 7.585 &, 110 & .743 \\
\hline Within Groups & 1722,933 & 25 & 68,917 & & \\
\hline Total & 1730,519 & 26 & & & \\
\hline
\end{tabular}

Gambar 4. Hasil Uji One Way Anova 


\section{Uji One Way Anova}

Hasil uji one way anova yang digunakan untuk melihat perbandingan kelimpahan ikan karangdi Fish shelter an di ekosistem Terumbu Karang Alami(TKA) Perairan Karang Melantut Pantai Rebo ditampilkan pada Gambar 4.

Berdasarkan hasil uji one way anova yang didapatkan maka tidak adanya perbedaan dari segi jumlah kelimpahan spesies yang signifikan. Nilai signifikansi di kedua lokasi pada masing-masing stasiun penelitian ditentukan dengan selang kepercayaan $95 \%$ atau nilai eror $5 \%$ sama dengan 0,05. Adapun nilai signifikansi yang di peroleh pada stasiun 1 yaitu 0,177 atau $\mathrm{H}_{0}$ diterima jika P-value $>0,05$. $\mathrm{H}_{0}$ Sedangkan pada stasiun 2 nilai signifikansi yang di peroleh yaitu 0.743 atau diterima jika P-value $>0,05$. maka jika $\mathrm{H}_{0}$ diterima menandakan perbandingan kelimpahan ikan karang di Fish Shelter dan di Terumbu Karang Alami(TKA) pada kedua stasiun tidak ada perbedaan nyata. Artinya untuk kedua stasiun bisa dilakukan peletakan Fish Shleter pada lokasi ekosistem terumbu karang yang rusak. Hal ini dikarenakan sama-sama memiliki respon yang baik dari ikan karang maupun organisme laut lainnya.

Adapun penyebab kelimpahan ikan karang pada stasiun 1 dan 2 dianggap sama atau tidak ada perbedaan nyata dikarenakan jarak antara peletakan fish shelter dengan ekosistem terumbu karang yang rusak cukup dekat yaitu \pm 5 - 10 meter. Selain itu, terdapatnya bubu para nelayan yang diletakan bersampingan dengan fish shelter, sehingga ikan-ikan yang terdapat pada daerah tersebut masuk kedalam bubu para nelayan.

\section{Persentase Tutupan Karang di Karang Melantut Pantai Rebo}

Hasil persentase tutupan karang di Perairan Karang Melantut Pantai Rebo ditampilkan pada Tabel 12. Adapun jumlah persentase tutupan karang hidup di Perairan Karang Melantut Pantai Rebo disajikan pada Gambar 5.

Hasil pengamatan persentase tutupan karang hidup (life coral) di Perairan Karang Melantut pada stasiun 1 sebesar 21,26\% yang termasuk dalam kategori buruk, dan stasiun 2 sebesar $32,88 \%$ termasuk dalam kategori sedang berdasarkan Keputusan Menteri Lingkungan Hidup No 4 Tahun 2001. Persentase tutupan karang hidup di kedua stasiun tergolong rendah. Selain itu, persentase tutupan karang yang rendah juga disebabkan karena adanya aktivitas pertambangan timah di sekitar pantai rebo yang berhadapan langsung dengan Karang Melantut.

Tabel 12. Persentase Tutupan Terumbu Karang di Perairan Karang Melantut.

\begin{tabular}{lcc}
\hline \multirow{2}{*}{ Kategori (Life Form) } & \multicolumn{2}{c}{ Karang Melantut \% } \\
\cline { 2 - 3 } & S1 & S2 \\
\hline Life Coral & 21.26 & 32.88 \\
DC (Dead Coral) & 14.94 & 23.96 \\
DCA (Dead Coral Algae) & 58.34 & 15.14 \\
AA (Algae Assemblage) & - & - \\
TA (Turf Algae) & 0.1 & - \\
MA (Macro Algae) & 0.2 & 14.04 \\
CA (Coralin Algae) & - & 2.14 \\
HA (Halimeda) & 0 & 0.14 \\
R (Rubble) & 2.04 & - \\
RCK (Rock) & - & - \\
SI (SIlt) & 1.02 & 0.44 \\
S (Sand) & 0.2 & 11.26 \\
WA (Water) & - & - \\
OT (Other) & 1.4 & - \\
SC (Soft Coral) & 0.5 & - \\
\hline & 100 & 100 \\
\hline
\end{tabular}

Persentase Tutupan Karang Hidup (\%)

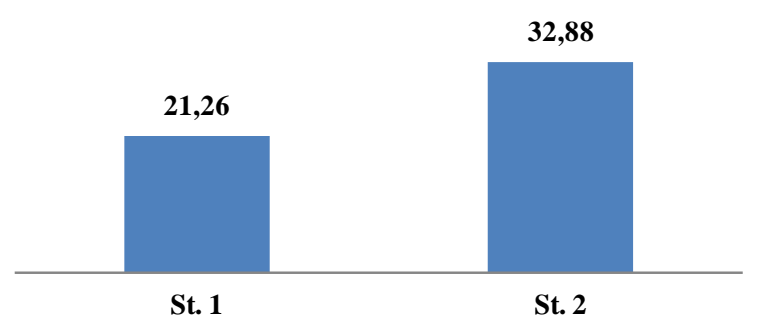

Gambar 5. Persentase Tutupan Karang

\section{Parameter Fisika Kimia perairan Karang Melantut Pantai Rebo.}

Adapun Data Parameter Lingkungan pada Perairan Karang Melantut Pantai Rebo ditampilkan Pada Tabel 13.

Hasil pengamatan pada parameter lingkungan di Perairan Karang Melantut Pantai Rebo didapatkan dengan suhu $30^{\circ} \mathrm{C}$. Terumbu karang dapat mentoleransi suhu sampai dengan $36-40{ }^{\circ} \mathrm{C}$ walaupun terumbu 
karang dapat tumbuh dan berkembang optimal pada perairan bersuhu rata-rata tahunan $23-25^{\circ} \mathrm{C}$. Mengacu pada literatur Keputusan Menteri Lingkungan Hidup nomor 51 tahun 2004 tentang Baku Mutu Air Laut untuk Biota Laut, nilai-nilai parameter perairan pada kedua lokasi penelitian termasuk ke dalam kondisi optimal bagi kehidupan biota laut, hal ini dibuktikan dengan nilai parameter suhu pada kedua lokasi penelitian berkisaran antara $29-30{ }^{\circ} \mathrm{C}$, dimana kisaran suhu tersebut tergolong layak bagi kelangsungan hidup Biota Laut khususnya bagi ikan karang (Hutagalung et al., 1997).

Nilai kecerahan perairan pada kedua lokasi penelitian tedapat perbedaan, dimana pada stasiun 1 nilai kecerahan perairan 100 $\%$ dengan kedalaman perairan 3-5 meter, hal ini dikarenakan pada lokasi ini berdekatan dengan ekosistem terumbu karang dan juga stasiun 1 merupakan daerah yang terlindung sehingga sedimentasi atau limbah tailing yang terbawa oleh arus kurang berdampak pada saat musim-musim tertentu, sedangkan nilai kecerahan perairan, berpengaruh terhadap produktifitas primer pada ekosistem terumbu karang melalui proses fotosintesis. Nilai kecerahan pada stasiun 2 berkisar antara $85 \%$ - 90\%. Hal ini dikarenakan pada saat pengambilan data dilakukan saat sedang musim peralihan yakni antara musim angin tenggara dengan musim angin timur, sehingga memiliki gelombang yang cukup tinggi dan angin yang relatif kencang.

Kecepatan arus di suatu perairan sangat diperlukan karena berguna bagi tersedianya aliran arus yang membawa makanan, oksigen dan jasad renik dari daerah Iain. Kecepatan arus di lokasi penelitian Perairan Karang Melantut Pantai Rebo memiliki rata-rata sebesar 0,1 dan $0,076 \mathrm{~m} / \mathrm{s}$. Kisaran yang diperoleh termasuk kedalam kisaran normal menurut Yusuf et al. (2012) sebesar $0,309 \mathrm{~m} / \mathrm{s}$ dengan rata-rata $0,055 \mathrm{~m} / \mathrm{s}$. sedangkan kisaran maksimum kecepatan arus yang baik untuk kehidupan biota laut khususnya ikan karang yaitu 0,2 $\mathrm{m} / \mathrm{s}$ (Haruddin et ai., 2011).

Nilai salinitas pada Perairan Karang Melantut Rebo pada stasiun 1 dan 2 memiliki rata-rata $31 \%$. Nilai ini masih dalam kategori normal untuk kehidupan biota laut, menurut Rizka (2006) bahwa kisaran nilai salinitas yang dikatagorikan normal bagi biota laut yaitu berkisar antara 30-36 \%o. Sedangkan menurut Romimohtarto dan Juwana (2009), bahwa kisaran nilai salinitas yang dikatagorikan normal bagi biota laut yaitu berkisar antara 30-35 \%o.

Nilai parameter $\mathrm{pH}$ di Perairan Matras dan Karang Melantut Rebo memiliki nilai parameter $\mathrm{pH}$ yang sama yaitu 7. Nilai $\mathrm{pH}$ sangat dipengaruhi oleh aktifitas fotosintesis dan suhu. Kisaran nilai $\mathrm{pH}$ yang diperoleh di lokasi penelitian termasuk kedalam kisaran yang normal untuk kehidupan organisme dalam perairan.

Nilai parameter DO atau oksigen terlarut di Perairan Karang Melantut Pantai Rebo yaitu kisaran 5,13-6,34 mg/L. Nilai oksigen terlarut di suatu perairan mengalami fluktuasi harian maupun musiman. Fluktuasi ini selain dipengaruhi oleh perubahan temperatur juga dipengaruhi oleh aktifitas fotosintesis dari tumbuhan yang menghasilkan oksigen. Ikan karang sangat sensitif terhadap kandungan oksigen terlarut kurang dari $2 \mathrm{mg} / \mathrm{l}$.

Tabel 6. Parameter Lingkungan di Perairan Karang Melantut Pantai Rebo

\begin{tabular}{|c|c|c|c|c|c|c|}
\hline \multirow{3}{*}{ Parameter } & \multicolumn{5}{|c|}{ Karang Melantut } & \multirow{3}{*}{ Sumber } \\
\hline & \multicolumn{2}{|c|}{ LAUT } & \multicolumn{2}{|c|}{ DARAT } & \multirow{2}{*}{$\begin{array}{l}\text { Baku } \\
\text { Mutu }\end{array}$} & \\
\hline & FS & TKA & FS & TKA & & \\
\hline $\mathrm{pH}$ & 7 & 7 & 7 & 7 & $7-8,5$ & KepMen LH, 2004 \\
\hline Salinitas $(\% 00)$ & 31 & 31 & 31 & 31 & $30-36$ & $\begin{array}{l}\text { Rohmimohtarto dan Juwana } \\
2009\end{array}$ \\
\hline Suhu $^{\circ} \mathrm{C}$ & 30 & 30 & 30 & 30 & $28-30{ }^{\circ} \mathrm{C}$ & KepMen LH, 2004 \\
\hline Arus $(\mathrm{m} / \mathrm{s})$ & 0.1 & 0.1 & 0.076 & 0.076 & 0,2 & Haruddin, 2011 \\
\hline $\begin{array}{l}\text { Kecerahan } \\
(\%)\end{array}$ & $\begin{array}{l}85 \\
\%\end{array}$ & $\begin{array}{l}90 \\
\%\end{array}$ & $\begin{array}{l}100 \\
\%\end{array}$ & $\begin{array}{c}100 \\
\%\end{array}$ & - & - \\
\hline $\mathrm{DO}(\mathrm{mg} / \mathrm{L})$ & 5.13 & 5.29 & 6.23 & 6.34 & $>5$ & KepMen LH, 2004 \\
\hline TSS (mg/L) & 15 & 14 & 13 & 15 & 20 & KepMen LH, 2004 \\
\hline
\end{tabular}


Nilai TSS atau partikel tersuspensi di Perairan Karang Melantut Pantai Rebo pada stasiun 1 dan 2 yaitu kisaran 13 - 15 mg/L. Menurut Keputusan Menteri Lingkungan Hidup nomor 51 tahun 2004 tentang Baku Mutu Air Laut untuk Biota Laut nilai TSS di ekosistem terumbu karang sebesar 20 mg/L, yang mengindikasikan ikan karang di Perairan Karang Melantut Pantai Rebo berada dalam kondisi normal.

\section{KESIMPULAN}

Kelimpahan ikan karang yang ditemukan di stasiun 1 pada ekosistem Terumbu Karang Alami(TKA) terdiri dari 8 famili dengan 16 spesies dan 10 famili dengan 12 spesies pada lokasi Fish Shelter. Sedangkan Kelimpahan ikan karang yang ditemukan di stasiun 2 pada ekosistem Terumbu Karang Alami(TKA) terdiri dari 7 famili dengan 12 spesies dan 10 famili dengan 15 spesies di lokasi Fish Shelter. Hasil uji one way anova pada stasiun 1 perbandingan kelimpahan ikan karang di lokasi Fish Shelter dan TKA dengan nilai signifikansi 0,177 , maka $\mathrm{H}_{0}$ diterima. sedangkan pada stasiun 2 perbandingan kelimpahan ikan karang di lokasi Fish Shelter dan TKA dengan nilai signifikan 0,743, maka $\mathrm{H}_{0} \quad$ diterima, artinya Perbandingan kelimpahan Ikan karang di fish shelter dan TKA pada stasiun 1 dan 2 sama-sama tidak ada perbedaan nyata dari segi jumlah kelimpahan spesies. Peletakan fish shelter di terumbu karang alami pada stasiun 1 dan 2 sama-sama memiliki respon dari organisme ikan karang dan dapat dijadikan sebagai habitat baru bagi organisme laut seperti ikan karang.

\section{REFERENSI}

English, S,C., Wilkinson, and V. Barker.1994. Survey Manual for Tropical Marine Resources. ASEAN-Australian Marine Project. Australia.

Haruddin, A., Edi, P., dan Sri, B. 2011. Dampak Kerusakan Ekosistem Terumbu Karang Terhadap Hasil Penangkapan Ikan Oleh Nelayan Secara Tradisional Di Pulau Siompu Kabupaten Buton Propinsi Sulawesi Tenggara. Jurnal Ekosains, 3 (3)

Hendrik, V.A. 2017. Analisis Struktur Komunitas Makroalga Ekonomis Penting di Perairan Intertidal Manokwari, Papua Barat. Jurnal Teknologi Perikanan dan Kelautan, 8 (1)
Hill, J., dan Wilkinson, C. 2004. Methods for Ecological Monitoring of Coral Reefs (Version 1). Australia Institute of Marine Science. Townsville, Australia.

Hutagalung, Y., Setiapermana, D., dan Riyono, S.H. 1997. Metode Analisis Air laut, Sedimen dan Biota. P3O. LIPI. Jakarta.

Kementerian Negara Lingkungan Hidup. 2004. Keputusan Menteri Negara Lingkungan Hidup No. 51 Tahun 2004. Tentang Baku Mutu Air Laut untuk Biota laut. Jakarta.

Kementrian Negara Lingkungan Hidup. 2001. Keputusan Menteri Negara Lingkungan Hidup Nomor 04 Tahun 2001. Tentang Kriteria Baku Kerusakan Terumbu karang. Jakarta.

Kementerian Negara Lingkungan Hidup. 2004.. Keputusan Menteri Lingkungan Hidup No.5. 2004. Tentang Baku Mutu Air Laut Untuk Biota Laut. Jakarta.

Madduppa, H. 2006. Laporan Pengamatan Agustus 2006 dan Analisis Perkembangan Biota Bentik dan Ikan Periode 2004-2006. Pemerintah Propinsi Daerah Khusus Ibukota Jakarta, Dinas Peternakan, Perikanan Dan Kelautan.

Odum, E.P. 1971. Dasar-Dasar Ekologi. Edisi ketiga Gadjah Mada University Press. Yogyakarta.

P2O-LIPI. 2013. Baku Mutu Kriteria Kelimpahan Ikan Karang. Jurnal Geologi Kelautan, 11 (3)

Rizka, L.S. 2006. Struktur Komunitas Ikan Karang pada Daerah Terumbu Karang Alami dan Transplantasi di Pulau Pramuka, Kepulauan Seribu, DKI Jakarta. [Tesis]. Pragram Studi Manajemen Sumberdaya Perairan Pantai. Universitas Diponegoro. Semarang.

Rohmimohtarto, K., dan Juwana, S. 2009. Biologi Laut: IImu Pengetahuan tentang Biologi Laut. Djambatan. Jakarta.

Setyobudiandi. 2009. Sampling dan Analisis Data Perikanan dan Kelautan Wilayah Pesisir dan Laut.Insitut Pertanian Bogor. Bogor.

Suharsono. 2010. Jenis-jenis Karang di Indonesia. LIPI Press. Jakarta.

Syari, I.A. 2016. Kondisi Terumbu Karang di Perairan Rebo Sungailiat Bangka Akibat Pertambangan Timah. Jurnal Akuatik $10(1): 13-20$.

Veron, J.E.N. 2000. Coral of The World. Vol1. Australia Institute of Marine Scinces, Townsville. 463p. 
Yusuf, M.., Handoyo, G., Muslim., Wulandari, S.Y., dan Setiyono, H. 2012. Karakteristik Pola Arus Dalam Kitannya Dengan Kondisi Kulaitas Perairan Dan
Kelimpahan Fitoplankton di Perairan Kawasan Taman Nasional Laut Nasional Laut Karimunjawa. Buletin Oseonografi Marina. FPIK. Universitas Diponegoro. 